\title{
Results of gas flux records in the seismically active area of Val d'Agri (Southern Italy)
}

\author{
Gerardo Colangelo $\left({ }^{1}\right)$, Jens Heinicke $\left({ }^{2}\right)$, Ulrich Koch $\left({ }^{2}\right)$, Vincenzo Lapenna $\left({ }^{1}\right)$, \\ Giovanni Martinelli $\left(^{(}\right)$and Luciano Telesca $\left({ }^{1}\right)$ \\ ( $\left.^{1}\right)$ Istituto di Metodologie per l'Analisi Ambientale (IMAA), CNR, Tito Scalo (PZ), Italy \\ ${ }^{(2)}$ Saechsische Akademie der Wissenschaften zu Leipzig, Arbeitsstelle Umweltforschung \\ mit Radiometrisch-geochemischen Methoden, Institut für Angewandte Physik, Freiberg, Germany \\ $\left(^{3}\right)$ ARPA - Agenzia Regionale Prevenzione e Ambiente dell'Emilia Romagna, \\ Sezione Provinciale di Reggio Emilia, Italy
}

\begin{abstract}
The Val d'Agri area is well-known for oil exploration. An old $500 \mathrm{~m}$ deep exploration well in the northern part of this area has been used for long-term hydrogeochemical investigations. The well is characterized by a discharge of about $500 \mathrm{~L} / \mathrm{min}$ of thermal water $\left(27.8^{\circ} \mathrm{C}\right)$ and a simultaneous methane gas emission of about $200 \mathrm{~L} / \mathrm{min}$. Gas analyses gave evidence that the methane come from a multiple deep reservoir. Continuous records of gas emission showed some anomalous variations occurred during the past three years. The gas flux anomalies were in a distinctive coincidence with self-potential anomalies of one station close to the hydrogeochemical station. The present paper describes the interpretation of these anomalies in relation to the geodynamic activity in the area.
\end{abstract}

Key words fluids - earthquakes - methane - gas emissions - flux anomalies

\section{Introduction}

Fluid pressure and its variation is an important mechanism for the transport of stress in the earth's crust (Hickman et al., 1995). Small perturbations of pore pressure are able to modify the effective stress and can induce seismic events (Zoback and Harjes, 1997; Shapiro et al., 2003). An aftershock sequence triggered by a fluid pres-

Mailing address: Dr. Luciano Telesca, Istituto di Metodologie per l'Analisi Ambientale (IMAA), CNR Area della Ricerca di Potenza, C.da S. Loja, 85050 Tito Scalo (PZ), Italy; e-mail: 1telesca@imaa.cnr.it sure pulse propagation coming from a deeper reservoir is discussed by Miller et al. (2004). Crampin (2003) proposed an increase of hydrostatic fluid pressure as being one part of the required stress before brittle faulting. That means that local stress variation will be transmitted by fluids through the open fracture system (Gudmundsson, 2000). Muir-Wood and King (1993) described these effects of stress propagation to the fluid transport system by seismic energy release. Pre- and co-seismic effects of changes in crustal permeability attributable to seismotectonic activity were reported by Toutain and Baubron (1999 and references therein), and Roeloffs et al. (2003 and references therein). Similar effects were expected in the test site area of Val d'Agri (Southern Apennines). The influence of crustal deformation processes, recognisable by a relatively high seismicity, on the local fluid dynamics was therefore investigated by means of hydrogeochemical and 
geoelectrical methods. For that purpose, the fluid emission of an unused exploration well was recorded. Anomalous fluid behaviour in seismic as well as volcanic active areas was also reported by Ito et al. (1999), Heinicke and Koch (2000) and Matsumoto et al. (2002, 2003).

\section{Geological and seismological settings}

The investigated area is located in Southern Apennine Chain, a Neogene and Quaternary foldand-thrust belt attributed to the subduction of Ionian lithosphere beneath the Adriatic plate (Doglioni et al., 1996). This part of the Apennines comprises a stack of east verging tectonic units representing an accretionary wedge composed of Mesozoic-Cenozoic sediments. Those were originally deposited in different paleogeographic domains, both basinal (Lagonegro) and shallow water platforms which were thrust onto the Apulian foreland to the east (Bonini and Sani, 2000).

In the present paper the Val d'Agri area, a NW-SE trending intermontane basin located in the Basilicata Apennine, has been focused. This fault-bounded basin is about $30 \mathrm{~km}$ long and $12 \mathrm{~km}$ wide and was formed during Quaternary in the interland of the fold and thrust belt after the major Miocene-Pliocene episodes of shortening (Giano et al., 2000).

The seismicity of the investigated area is related to the Irpinia normal faults, the Potenza strikeslip fault and the Val d'Agri normal faults. The Val d'Agri fault system consists of roughly N120 trending left-lateral strike-slip faults (Monaco et al., 1998) and associated features including mainly: i) N020-N030 trending right-lateral/transtensional faults; ii) N090-N110 trending, left-lateral transtensional faults; and N120-N150 trending, left-lateral transpressional faults (see fig. 1a,b). About the Potenza strike-slip fault the focal mechanism calculated for the main shock (May 5, $1990, M_{L}=5.2$ ) shows a strike slip solution with a N70E $T$-axis and a N163E $P$-axis (Azzara et al., 1993). For the Irpinia area, a strike angle of $320^{\circ}$ and a dip angle of $70^{\circ} \mathrm{NE}$ has been calculated for the main normal faults (Vaccari et al., 1990).

Historically one of the most important events, the normal-faulting earthquake of December $16,1857\left(I=\mathrm{XI}^{\circ} \mathrm{MCS} ; M_{e}=6.9\right)$, occurred in the NW part of the Val d'Agri (Mallet, 1862; Boschi et al., 1997). This earthquake was

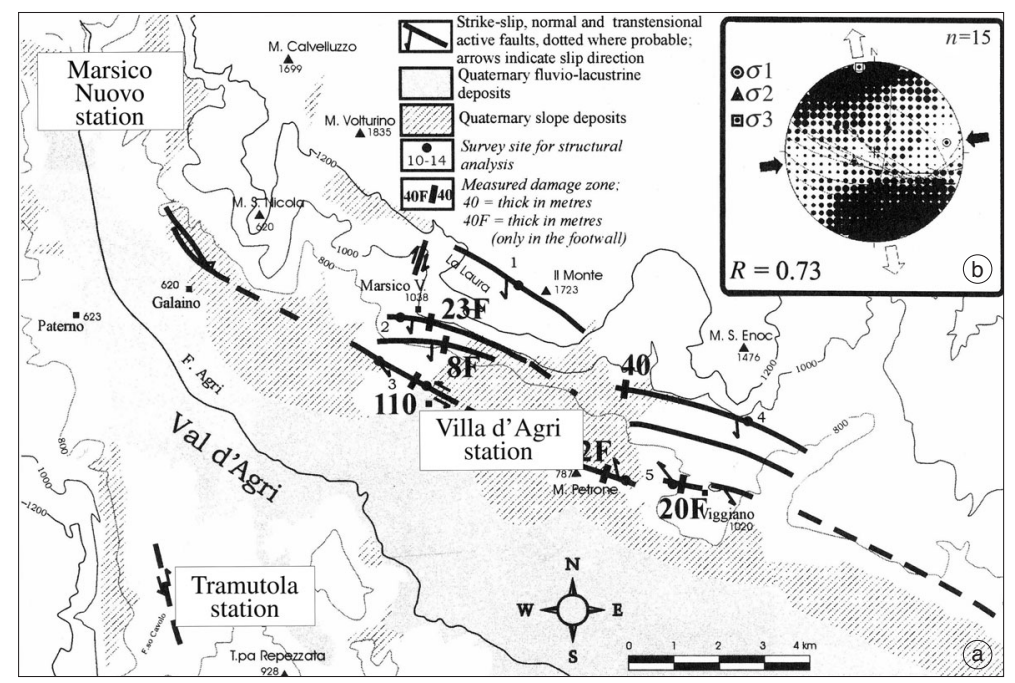

Fig. 1a,b. a) Map of the active faults, b) stress field geometry in Val d'Agri region (from Cello et al., 2003) and the locations of the hydrogeochemical station of Tramutola and the $S P$-station of Marsico Nuovo and Villa d'Agri. 


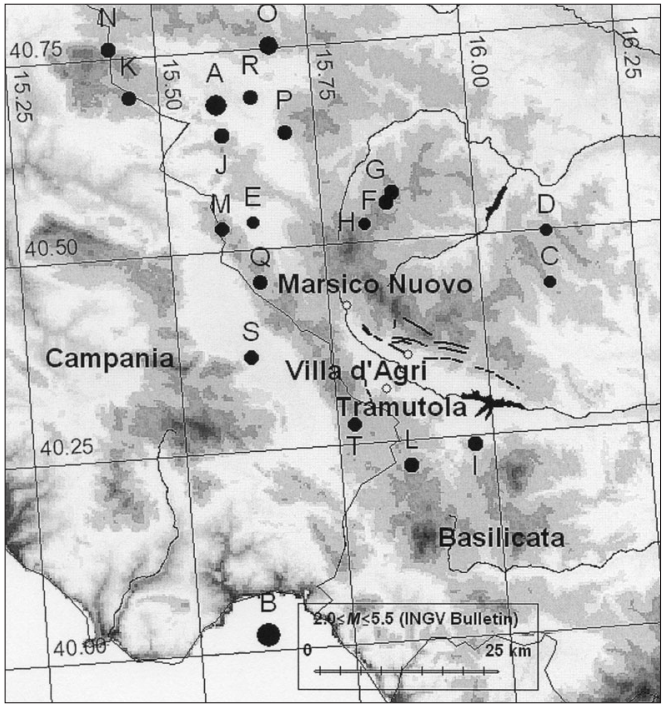

Fig. 2. Spatial distribution of epicentres of the seismic events A-T (black dots, see table I) during anomalous gas flux periods and their relation to the Tramutola, Marsico Nuovo and Villa d'Agri station (white circle).

characterized by an epicentral area which extended in a roughly NW-SE direction from the northern Vallo di Diano to the Val d'Agri area, for a total length of about $60 \mathrm{~km}$ and a width of more than $10 \mathrm{~km}$ (Cello et al., 2003). The stress field responsible for the genesis and evolution of the fault systems ( $\sigma$ l, sub-horizontal) is WSW-ENE trending (Cello et al., 2003). Upgraded stress field data in the studied area have recently been reported by Cucci et al. (2004) with a NE-SW direction of extension.

On November 23, 1980, a strong earthquake $\left(M_{s}=6.9\right)$ struck the area north of Val d'Agri, the Campano-Lucano Apennines. The 1980 Irpinia earthquake was characterised by three distinct subevents occurring within $40 \mathrm{~s}$ along different faults. Seismic activity after the 1980 event consisted of medium intensity events $(M<5.5)$ located close to the border between the Campania and Basilicata regions (Alessio et al., 1995).

Besides the strong historical seismicity, the local seismicity with low-middle strong events
$\left(M_{L}=1, \ldots, 5\right)$ is still active. We selected several seismic events from the INGV Internet Bulletin (www.ingv.it) for our interpretation (see fig. 2 and table I). Important for our selection was an empirical frame: a distance to the hydrogeochemical station of less than $60 \mathrm{~km}$ (in coordinates: $40.0-40.8 \mathrm{~N}$ and $15.3-16.1 \mathrm{E}$ ), the foci not deeper than $25 \mathrm{~km}$ and an occurrence in a time window of three weeks before and after the anomaly. All seismic events used for our interpretation are marked by a symbol, the capital letters A-T, and documented in fig. 2.

Table I. All seismic events occurring in Val d'Agri region within the co-ordinates of $40.0-40.8 \mathrm{~N}$ and 15.3-16.1E and the foci not deeper than $25 \mathrm{~km}$ with possible temporal relations to the recorded flux anomalies; focal depth in km (INGV Bulletin). Figure 2 show the epicentre with the symbols.

\begin{tabular}{cccccc}
\hline \hline Date & Lat. & Long. & $M$ & Depth & Symbol \\
\hline 03.04 .1996 & $40.683 \mathrm{~N}$ & $15.550 \mathrm{E}$ & 4.9 & 8.0 & $\mathrm{~A}$ \\
09.09 .1998 & $40.020 \mathrm{~N}$ & $15.570 \mathrm{E}$ & 5.5 & 11.0 & $\mathrm{~B}$ \\
04.11 .2001 & $40.393 \mathrm{~N}$ & $16.052 \mathrm{E}$ & 2.0 & 10.0 & $\mathrm{C}$ \\
04.11 .2001 & $40.458 \mathrm{~N}$ & $16.162 \mathrm{E}$ & 2.0 & 4.4 & $\mathrm{D}$ \\
04.11 .2001 & $40.492 \mathrm{~N}$ & $15.580 \mathrm{E}$ & 2.0 & 13.1 & $\mathrm{E}$ \\
21.11 .2001 & $40.547 \mathrm{~N}$ & $15.814 \mathrm{E}$ & 2.8 & 19.7 & $\mathrm{~F}$ \\
21.11 .2001 & $40.560 \mathrm{~N}$ & $15.824 \mathrm{E}$ & 2.6 & 11.3 & $\mathrm{G}$ \\
21.11 .2001 & $40.523 \mathrm{~N}$ & $15.776 \mathrm{E}$ & 2.0 & 22.6 & $\mathrm{H}$ \\
08.02 .2002 & $40.239 \mathrm{~N}$ & $15.927 \mathrm{E}$ & 2.6 & 10.0 & $\mathrm{I}$ \\
14.02 .2002 & $40.644 \mathrm{~N}$ & $15.557 \mathrm{E}$ & 2.6 & 10.0 & $\mathrm{~J}$ \\
19.02 .2002 & $40.699 \mathrm{~N}$ & $15.411 \mathrm{E}$ & 2.4 & 9.4 & $\mathrm{~K}$ \\
26.02 .2002 & $40.218 \mathrm{~N}$ & $15.822 \mathrm{E}$ & 2.6 & 10.0 & $\mathrm{~L}$ \\
03.03 .2002 & $40.529 \mathrm{~N}$ & $15.544 \mathrm{E}$ & 2.1 & 10.0 & $\mathrm{M}$ \\
24.01 .2003 & $40.762 \mathrm{~N}$ & $15.384 \mathrm{E}$ & 2.6 & 9.9 & N \\
03.02 .2003 & $40.753 \mathrm{~N}$ & $15.643 \mathrm{E}$ & 3.6 & 8.4 & $\mathrm{O}$ \\
03.02 .2003 & $40.751 \mathrm{~N}$ & $15.669 \mathrm{E}$ & 3.5 & 8.0 & No \\
04.02 .2003 & $40.783 \mathrm{~N}$ & $15.661 \mathrm{E}$ & 2.8 & 9.7 & No \\
04.02 .2003 & $40.643 \mathrm{~N}$ & $15.659 \mathrm{E}$ & 2.5 & 9.8 & $\mathrm{P}$ \\
07.02 .2003 & $40.459 \mathrm{~N}$ & $15.600 \mathrm{E}$ & 2.3 & 5.0 & $\mathrm{Q}$ \\
12.02 .2003 & $40.690 \mathrm{~N}$ & $15.608 \mathrm{E}$ & 2.3 & 11.0 & $\mathrm{R}$ \\
16.02 .2003 & $40.367 \mathrm{~N}$ & $15.576 \mathrm{E}$ & 2.2 & 15.9 & S \\
16.02 .2003 & $40.274 \mathrm{~N}$ & $15.735 \mathrm{E}$ & 2.1 & 16.2 & $\mathrm{~T}$ \\
\hline & & & & &
\end{tabular}




\section{Analysis of hydrogeochemical and geoelectrical signals}

Geological and seismological features, combined with a very low level of anthropogenic noise, allow us to consider the selected area a test site to study the possible correlations between tectonic activity and anomalous patterns in hydrogeochemical and geoelectrical signals. In 2000 the Institute of Methodologies for Environmental Analysis (National Council of Research, Potenza, Italy) installed a monitoring network to detect geophysical, hydrogeochemical and seismometric parameters in the Basilicata region (Balasco et al., 2001). Two remote stations of this network are recording self-potential signals: Marsico Nuovo $(40.416 \mathrm{~N}, 15.722 \mathrm{E})$ and Villa d'Agri $(40.372 \mathrm{~N}, 15.803 \mathrm{E})$ and a third station is recording hydrogeochemical parameters: Tramutola (40.322N; 15.759E) (figs. 1a,b and 2).

\subsection{Self-potential stations}

These geoelectrical recordings started at Marsico Nuovo station in November 2000 and in Villa d'Agri station in September 2001. The self-potential recording consists of measurements at the earth's surface, recording the electrotelluric field developed in the subsurface by several mechanisms such as electrokinetic coupling (self-potential) and electrochemical effects (Corwin and Hoover, 1979).

The electrical field is due to the relative displacement between the charged mineral grains and the pore water. This drags the excess of electrical charge, located in close vicinity to the pore water/mineral interface, into the socalled electrical double layer (Revil and Leory, 2001). This phenomenon produces a net current density, which serves as a source term in the Maxwell equations. These electrokinetic effects are known as streaming potential. In addition, this electric field is strong enough to be recorded at the ground surface using non-polarizable electrodes (Revil, 2002). Other theories also attribute self-potential signal generation to charge motions in crystalline solid materials at depth (see also Vallianatos et al., 1999 and references therein).
The self-potential acquisition system used in the Val d'Agri stations consists of an array with $1.5 \mathrm{~m}$ long copper electrodes (6 in Marsico Nuovo and 2 in Villa d'Agri), put into the ground at 1 $\mathrm{m}$ depth. The electrodes spacing is between 60$80 \mathrm{~m}$. They are linked up with a high-resolution acquisition unit (16 bit) connected to a $\mathrm{PC}$ with a serial interface. The sampling rate is one second.

\subsection{Hydrogeochemical station}

After the strong 1857 Val d'Agri earthquake, an unusual natural emission of oily fluids took place close to the Tramutola village. Just a few tens of meters away a $500 \mathrm{~m}$ deep well for oil exploration was drilled in 1956. The well, which crosses clay, silicic clays, and silicic limestones belonging to the Lagonegro units, encountered an artesian aquifer emitting thermal water and gas.

The well is currently utilised for scientific purposes. Italiano et al. (2001) investigated geochemical parameters and isotopes by manual sampling techniques. The gas emission is methanedominated (> 80\%) and showed significant shortterm variations in the composition due to local seismogenic processes. The water, spontaneously discharged from the well at a rate of $500 \mathrm{~L} / \mathrm{min}$, is of a Na- $\mathrm{HCO}_{3}-\mathrm{Cl}$ type. The water temperature is $27.8^{\circ} \mathrm{C}$. The isotopic composition disclosed a meteoric water origin, since $\delta^{18} \mathrm{O}$ and $\delta \mathrm{D}$ values are on the local meteoric water line. The chemistry of the thermal water is related to the process of carbonate dissolution and subsequent cation exchange in deeper reservoirs. The $R / R a$ ratio of the Helium isotopes is $>1$ and indicates a mantle contribution, which is also supported by the $\delta^{13} \mathrm{C}$ data of the $\mathrm{CO}_{2}$ components of $-3.5 \%$ o.

The hydrogeochemical station of Tramutola, whose acquisition started in May 2001, is able to record several parameters. A gas counter was installed to record a part of the natural gas flux from the well. Due to different installation set ups with different sampling tubes and gas counters, the recorded gas flux ranged between 4 and $50 \mathrm{~L} / \mathrm{min}$. One part of the emitted gas flux is collected in a long plastic tube of $30 \mathrm{~cm}$ diameter directly above the borehole. A smaller tube transports the gas to the counter. The gas flux is recorded by counting the electric pulses per 10 


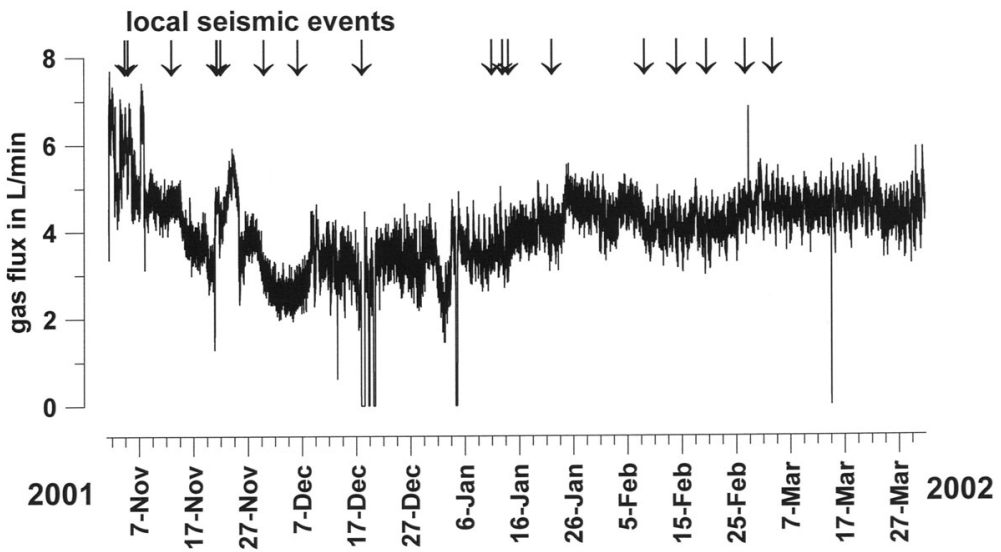

Fig. 3. Temporal variation of the gas flux recorded at Tramutola station during the first measurement period from November 2001 to March 2002 and their local seismicity.

min by a drum gas counter. The recording error is less than $1 \%$. Other parameters recorded by the Tramutola station are the atmospheric pressure, water and environment temperatures and, since May 2003, two self-potential dipoles along $\mathrm{N}-\mathrm{S}$ and E-W directions. The records of gas flux show no response to tidal effects. The typical correlation to atmospheric pressure variation, observed on mineral springs (Koch et al., 2003) or on volcanic gas emission sites (Shimoike and Notsu, 2000) was not observed due to the artesian discharge from the deep reservoir.

Figure 3 shows the first period of continuous gas flux records before the records were disturbed partly due to technical problems. A possible relation to local seismic events will be discussed in the following paragraphs.

\subsection{Previously recorded data}

During the past three years some anomalies in the gas flux have been recorded. The macroscopically observed flow rate as well as the chemical and isotopic compositions of the Tramutola gas emission changed significantly in connection with the seismic event occurring on April 3, 1996, north of Tramutola $\left(M_{L}=4.9\right.$; epicentral distance $45 \mathrm{~km}$, symbol A in fig. 2) (Italiano et al., 2001). The gas emission
Table II. Gas composition in normal conditions and during the seismic crisis.

\begin{tabular}{lcccc}
\hline \hline Gas in vol\% & $\mathrm{CH}_{4}$ & $\mathrm{He}(\mathrm{ppm})$ & $\mathrm{N}_{2}$ & $\mathrm{CO}_{2}$ \\
$\begin{array}{l}\text { Normal gas } \\
\text { composition }\end{array}$ & 83 & 230 & 13 & 1.4 \\
$\begin{array}{l}\text { During the } \\
\text { seismic crisis }\end{array}$ & 38 & 69 & 59 & 3.1 \\
\hline
\end{tabular}

changed from a methane dominated phase to a nitrogen dominated one and back to normal after the seismic crisis (table II) mixing processes occurred which were probably induced by the seismogenic process.

Pore pressure increase in the upper nitrogen dominated reservoir, or gas pressure reduction in the deeper methane dominated reservoir could have generated the recorded anomaly. A second strong event $(M=5.5)$ which occurred in September 1998 induced no variation in the chemical composition of the water. The epicentre (epicentral distance $38 \mathrm{~km}, \mathrm{~B}$ ) was probably outside the seismogenic influenced fluid system, which seems to be trending more N-NW. A parallel $130^{\circ} \mathrm{N}$-trending seismogenic zone (Cucci et al., 2004) provide further arguments for an open fluid system in that direction. 


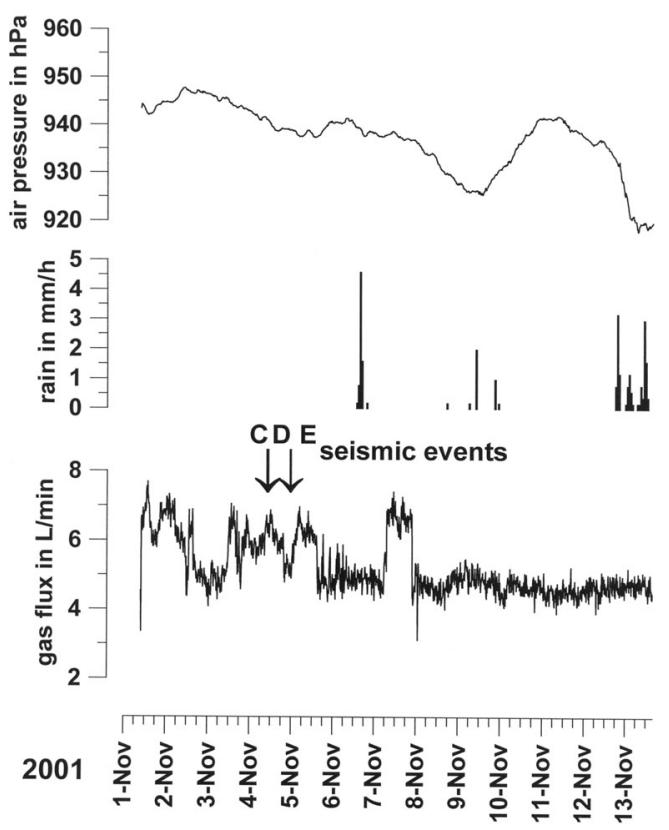

Fig. 4. Temporal variation of the gas flux and atmospheric pressure recorded at Tramutola station in the period from November 1 to 13, 2001. The capital letters $\mathrm{C}, \mathrm{D}$ and $\mathrm{E}$ are local seismic events in that period. Their epicentres are presented in table I and fig. 2.

\subsection{Anomalous data recorded in November 2001}

Two periods of hydrogeological anomalies occurred in November 2001.

At the beginning of our records on November 1,2001 , after a gap in recording, immediately we recorded a period of anomalous gas variations with higher gas flux of around 6-7 L/min up to November 8 (fig. 4). The following period shows the normal flux of around 3-4 L/min. Barometric pressure variations were not responsible for this increased gas flux.

If these anomalous phenomena were generated by the same causes that induced the anomalies recorded in the flux and in the gas composition in 1996 we infer that the observed anomalies can be related to local geodynamic processes testified by one of the seismic events of November 4 (table I and figs. 2 and 4). Other events in that area and period occurred on October 13 and on November
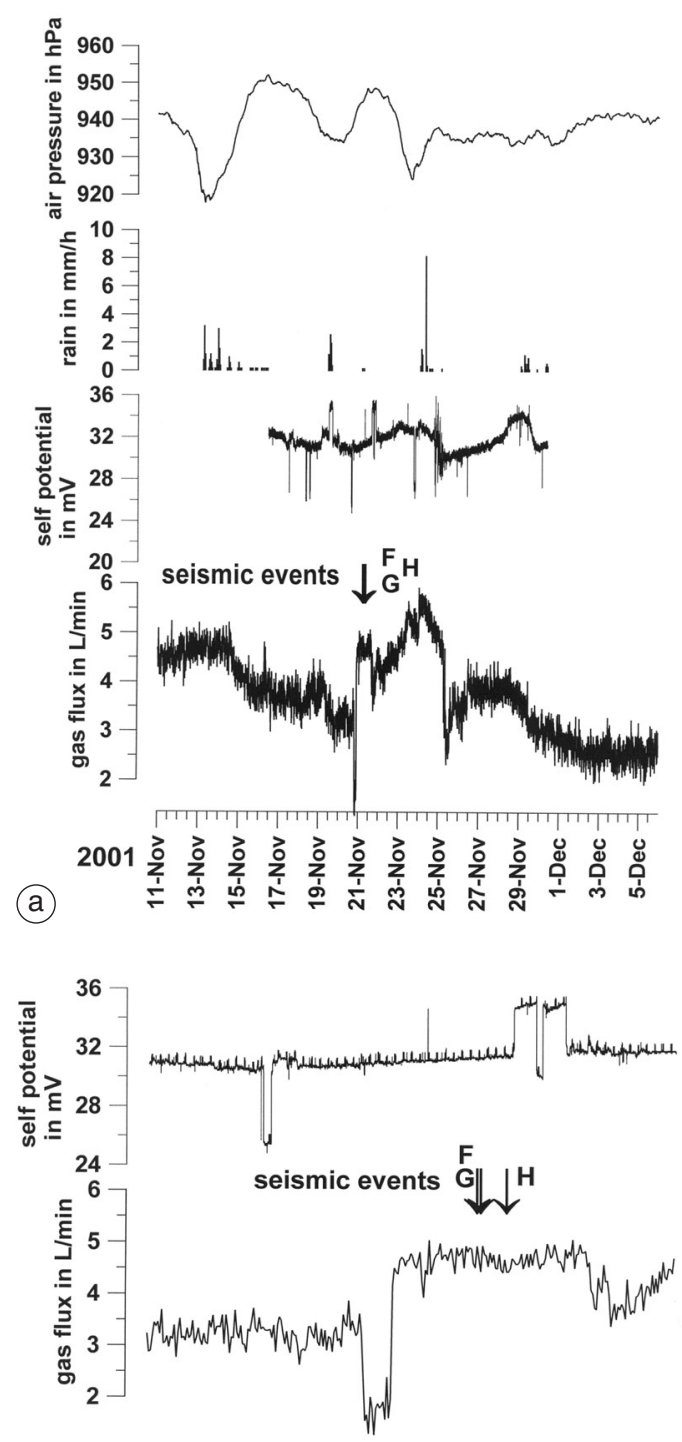

(b)

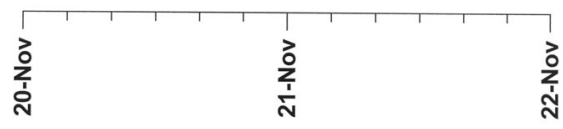

Fig. 5a,b. a) Temporal variation of the gas flux, rain and atmospheric pressure recorded at the Tramutola station and the self potential signal recorded at Marsico Nuovo in the period from November 11 to December 6, 2001. Local seismic events in that period: F, G and H. b) Enlarged part of the temporal variation of gas flux and self potential signal in the anomalous period from November 20 to 22, 2001. 
21. The events of November 21, have occurred north of Tramutola in the Val d'Agri area (table I), could be responsible for a further anomaly on the same day. The distance from the main event to Tramutola station is about $18 \mathrm{~km}$ (fig. 2). An anomalous fluid emission had been recorded some hours before these events.

Figure 5a shows the second gas flux anomaly at Tramutola station: an anomalous pattern in the signal is visible between November 20 and 25 . This anomaly is characterized by a sharp decrease and increase occurring several hours before the earthquakes $\mathrm{F}, \mathrm{G}$ and $\mathrm{H}$ (fig. 5b). The gas flux increased from 4 to $6 \mathrm{~L} / \mathrm{min}$ at $10 \mathrm{p} . \mathrm{m}$. on November 20. Concomitantly, an anomalous decrease in the self-potential signal to a level of $25 \mathrm{mV}$ in the E-W signal was recorded at Marsico Nuovo $S P$-station on November 20 followed by a positive anomaly co-seismically on November 21. No rain influenced that region during these days.

\subsection{Anomalous data recorded in February 2002}

A third gas flux anomaly was recorded on February 27, 2002 as a spike like gas eruption with a duration of one hour (fig. 6). The gas flux increased from around $4.5 \mathrm{~L} / \mathrm{min}$ to $6.9 \mathrm{~L} / \mathrm{min}$. In the same period on February 26 a $M=2.6$ earthquake (L) occurred close to the Tramutola station. Furthermore, the geoelectrical signal recorded at Marsico Nuovo station, showed an anomaly characterised by a sharp negative variation on February $26-c a .7 \mathrm{~h}$ before the seismic event. No rainfall was observed in the same period. Other seismic events close to the stations during that period are listed in table I.

\subsection{Anomalous data recorded in February 2003}

A further example of significant gas flux anomaly occurred on February 8, 2003 (fig. 7). This short term peak lasting $3 \mathrm{~h}$ was not accompanied by a self-potential anomaly. The gas flux increased from 16 to $24 \mathrm{~L} / \mathrm{min}$. A seismic event of magnitude 2.3 occurred $9 \mathrm{~h}$ before the recorded anomaly. Further seismic events are listed in table I.

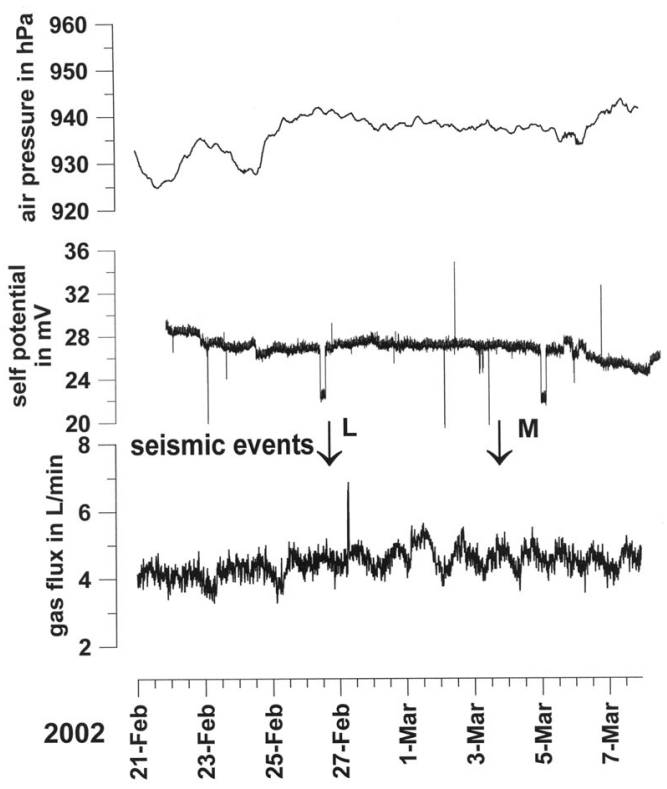

Fig. 6. Temporal variation of the gas flux and atmospheric pressure recorded at the Tramutola station and the self potential signal recorded at Marsico Nuovo in the period from February 21 to March 7, 2002. $\mathrm{L}$ and $\mathrm{M}$ are local seismic events in that period.
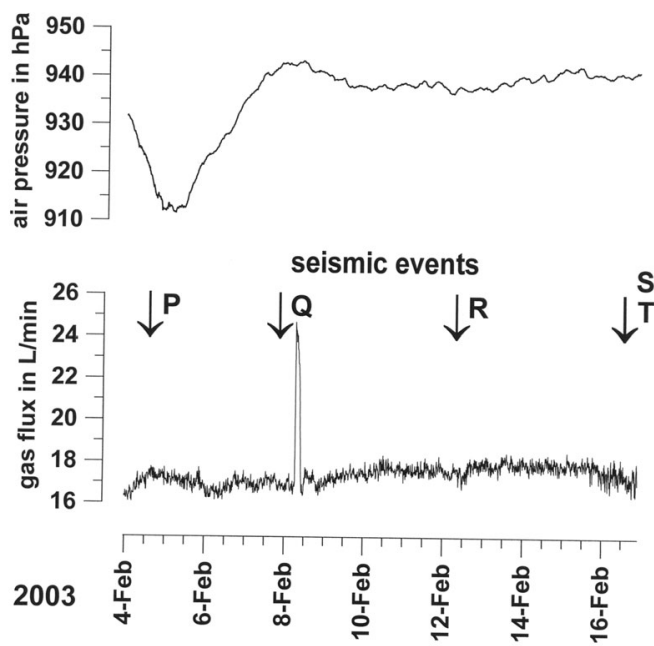

Fig. 7. Temporal variation of the gas flux and atmospheric pressure recorded at the Tramutola station in the period from February 4 to February 16, 2003. P, $\mathrm{Q}, \mathrm{R}, \mathrm{S}$ and $\mathrm{T}$ are local seismic events in that period. 


\section{Discussions}

The four gas flux anomalies presented here show different patterns in their duration but also some common features. In particular a significant increase in gas flux characterises each of the anomalous periods, which could be related to a compression process. Anomalous water temperature variations were not observed.

The anomalies in the investigated period were represented by an increase in gas flux with long term variations in November 2001 and short term peaks in the following two years. Italiano et al. (2001) showed that fluctuations in the fluid composition of Tramutola well were recorded and accompanied by a macroscopically observed variation in the flow rate. In 1995, the nitrogen content increased from approximately $15 \%$ to $50 \%$ in comparison to methane content during the anomalous period. If the methane content was constant, the nitrogen content increased six times so that the whole gas flux increased from $100 \%$ to $170 \%$. The relatively stable $\mathrm{He} 3 / 4$ ratio supports this idea. The recently recorded gas flux anomalies also show an increase of about $150 \%$. These additional amounts of gas could be related to a variation in the local stress field. The influences on fault permeability during crustal deformation processes could induce the temporal variations in the gas emission. Long-term gas flux anomalies having been recorded before the seismic events on November 2001 could be interpreted with a long-term pressure increase on the fluid conduits. Obviously, not each of the stress accumulation stages before local events influences the fluid transport parameter. Only a few anomalies were recorded in that seismically active region.

The two short term anomalies occurring 10-13 h after the seismic events in 2001 and 2002 are so called post-seismic anomalies. Geodynamic processes, like hydro-fracturing or a fast conduits compression, could possibly characterise this type of short term anomaly generation. Matsumoto et al. (2003) suggest ground motion due to the earthquake for interpretation. In all cases, probably the upper nitrogen filled horizons are the resources for that increase in the flux rate.
The NNW-SSE oriented fault structure at Tramutola as main fault gauge is influenced by the regional stress field of $\sigma 1$ in WNW-ESE (Cello et al., 2003). Stress accumulation could be responsible here as an influencing factor to induce fluid flux anomalies. Figure 2 shows a distribution of all mentioned events A-T which could be related to the recorded anomalies. However, an unproven/weak correlation is recognisable: for all anomalies seismic events exist along the NW-SE trending Val d'Agri fault line, in particular: A, E, (F, G, H), L and Q. All epicentres, except B, C and D, were located in a N-NW trending fault zone which is characterised by the main compression zone, a suitable conduit for anomalous high pore pressure. The distances between the epicentres and Tramutola are less than $50 \mathrm{~km}$.

Furthermore self-potential anomalies were simultaneously recorded in two cases: November 2001 and February 2002. These anomalies were recorded only in Marsico Nuovo. Probably, similar to the gas flux anomalies of Tramutola, short term anomalies in the fluid transport process could here also be responsible for these $S P$ variations. The idea of regional/local stress/pressure propagation will be supported due to the fact that both stations are located in the same part of the fault structure. Temporal differences in the anomaly occurrence could express the dynamics of this process. The second self potential station at Villa d'Agri on the East side of the fault zone showed no anomalies during that period.

\section{Conclusions}

Significant anomalies in hydrogeochemical and geoelectrical signals recorded in Val d'Agri by remote stations have been related to the occurrence of seismic events, whose epicentres are located close to the stations. Since the influence of meteorological factors on the abnormal fluctuations of geoelectrical and geochemical data has been excluded, these fluctuations can be attributed to crustal deformation processes, though not all local seismic events were preceded or followed by this kind of fluid anomalies. 


\section{REFERENCES}

Alessio, G., F. Esposito, A. Gorini and S. Proofed (1995): Detailed study of the Potation seismic zone in the Southern Apennines, Tectonophysics, 250, 113-134.

Azzara, R., A. Basili, L. Beranzoli, C. ChiarabBa, R. Di Giovambattista and G. SelvagGi (1993): The seismic sequenze of Potenza (May 1990), Ann. Geofis., XXXVI (1), 237-243.

Balasco, M., D. Chianese, G. Di Bello, M.R. Gallipoli and V. LAPENNA (2001): A new multiparametric geophysical station to detect self-potential and seismometric signals at Tito site (Southern Italy), Ann. Geofis., 44 (2), 193-203

Bonini, M. and F. SANI (2000): Pliocene-Quaternary transpressional evolution of the Anzi-Calvello and Northern S. Arcangelo basins (Basilicata, Southern Apennines, Italy) as a consequence of deep-seated fault reactivation, Mar. Pet. Geol., 17, 909-927.

Boschi, E., E. Guidoboni, G. Ferrari, G. Valensise and P. GASPERINI (Editors) (1997): Catalogo dei Forti Terremoti in Italia dal 461 a.C. al 1990 (ING, Roma - SGA, Bologna), vol. 2, pp. 644.

Cello, G., E. Tondi, L. Micarelli and L. Mattioni (2003): Active tectonics and earthquake sources in the epicentral area of the 1857 Basilicata earthquake (Southern Italy), $J$. Geodyn., 36, 37-50.

Corwin, R.F. and D.B. Hoover (1979): The self-potential method in geothermal exploration, Geophysics, 44, 226-245.

Crampin, S. and S. Peacock (2003): Seismic evidence for fluid-driven deformation, J. Geodyn., 36, 67-77.

Cucci, L., S. Pondrelli, A. Frepoli, M.T. Mariucci and M. Moro (2004): Local pattern of stress field and seismogenic sources in the Pergola-Melandro Basin and the Agri Valley (Southern Italy), Geophys. J. Int., 156, 575-583.

Doglioni, C., P. Harabaglia, G. Martinelli, F. MongelLI and G. Zito (1996): A geodynamic model of the Southern Apennines accretionary prism, Terra Nova, 8, 540-547.

Giano, I., V. Lapenna, S. Piscitelli and M. Schiattarella (2000): Electrical imaging and self-potential surveys to study the geological setting of the Quaternary slope deposits in the Agri high valley (Southern Italy), Ann. Geofis., 43 (2), 409-419.

Gudmundsson, A. (2000): Active fault zones and groundwater flow, Geophys. Res. Lett., 27, 2993-2996.

Heinicke, J. and U. Koch (2000): Slug flow - A possible explanation for hydrogeochemical earthquake precursors at Bad Brambach, Germany, Pure Appl. Geophys., 157, 1621-1641.

HickMANN, S., R. SiBSON and R. BRUHN (1995): Introduction to special section: mechanical involvement of fluids in faulting, J. Geophys. Res., 100, 12831-12840.

Italiano, F., M. Martelli, G. Martinelli, P.M. Nuccio and M. PAternoster (2001): Significance of earthquake-related anomalies in fluids of Val d'Agri (Southern Italy), Terra Nova, 13, 249-257.

Ito, T., K. Nagamine, K. Yamamoto, M. Adachi and I. KAWABE (1999): Preseismic hydrogen gas anomalies caused by stress-corrosion process preceding earthquakes, Geophys. Res. Lett., 26, 2009-2012.
Koch, U., J. Heinicke and M. Vossberg (2003): Hydrogeological effects of the latest Vogtland-NW Bohemian swarmquake period (August-December 2000), J. Geodyn., 35, 107-123.

MaLlet, R. (1862): The Great Neapolitan Earthquake of 1857. The First Principle of Observational Seismology (London), vol. 1, pp. 431 and vol. 2, pp. 339.

Matsumoto, N., T. Sato, N. Matsushima, F. Akita, T. ShiBATA and A. SUZUKI (2002): Hydrological anomalies associated wuth crustal deformation before the 2000 eruption of Usu volcano, Japan, Geophys. Res. Lett., 29, doi:10.1029/2001GL013968.

Matsumoto, N., G. Kitagawa and E. Roeloffs (2003): Hydrological response to earthquakes in the Haibara well, Central Japan, I. Groundwater level changes revealed using state space decomposition of atmospheric pressure, rainfall and tidal responses, Geophys. J. Int., 155, 885-898.

Miller, S.A., C. Collettini, L. Chiaraluce, M. Cocco, M. BARCHI and B.J.P. KAUS (2004): Aftershocks driven by a high-pressure $\mathrm{CO}_{2}$ source at depth, Nature, 427, 724-727.

Monaco, C., L. Tortorici and W. PALtrinieri (1998): Structural evolution of the Lucania Apennines, J. Struct. Geol., 20, 617-638.

MuiR-Wood, R. and G.C.P. KING (1993): Hydrological signatures of earthquake strain, J. Geophys. Res., 98, 22035-22068.

REVIL, A. (2002): The hydroelectric problem of porous rocks: thermodynamic approach and introduction of a percolation threshold, Geophys. J. Int., 151, 1-6.

ReVIL, A. and P. LEORY (2001): Hydroelectric coupling in a clayey material, Geophys. Res. Lett., 28, 1643-1646.

Roeloffs, E., M. Sneed, D. Galloway, M. Sorey, C. Farra, J. Howle and J. HuGHES (2003): Water-level changes induced by local and distant earthquakes at Long Valley caldera, California, J. Volcanol. Geotherm. Res., 127, 269-303.

SHAPIRO, S.A., R. PATZIG, E. ROTHERT and J. RindSCHWENTNER (2003): Triggering of seismicity by pore-pressure pertubations: permeability-related signatures of the phenomenon, Pure Appl. Geophys., 160, 1051-1066.

ShIMOKE, Y. and K. Notsu (2000): Continuous chemical monitoring of volcanic gas in Izu-Oshima volcano, Japan, J. Volcanol. Geotherm. Res., 101, 211-221.

ToutAin, J.-P. and J.-C. BAubron (1999): Gas geochemistry and seismotectonics: a review, Tectonophysics, 304, 1-27.

Vaccari, A., P. Harabaglia, P. Suhadolc and G. F. Panza (1993): The Irpinia (Italy) 1980 earthquake: waveform modelling of accelerometric data and macroseismic consideration, Ann. Geofis., XXXVI (1), 93-108.

VAllianatos, F. and A. Tzanis (1999): A model for the generation of precursory electric and magnetic fields associated with the deformation rate of the earthquake focus, in Seismic Atmospheric and Ionospheric Electromagnetic Phenomena, edited by M. Hayakawa (Terra Sci. Publ. Co., Tokyo), 287305.

ZoBACK, M. and H.-P. HARJES (1997): Injection induced earthquakes and the crustal stress at $9 \mathrm{~km}$ depth at the KTB deep drilling site, Germany, J. Geophys. Res., 102, 18477-18492. 